------ Raf. J. Sci., Vol. 24, No.3 pp. 1-16, 2013 ------

\title{
Detection of Antisperm Antibodies in Relation to Inhibin B in Infertile Men
}

\author{
Ruaa E. Shaya \\ Nawfal Y. Al-Dabbagh \\ Department of Microbiology \\ College of Medicine \\ University of Mosul
}

(Received 14/8/2012 ; Accepted 26/11/2012)

\begin{abstract}
Antisperm antibodies (ASAs) was considered as an immunological cause of male infertility. Serum inhbin B has a strong relationship with spermatogenesis and can be considered as a cause of infertility. The aims of the study are to: 1-Detect the presence of antisperm antibodies in both sera and seminal plasma of infertile patients and control group. 2- Find the effect of antisperm antibodies in seminal fluid parameters. 3- Exclude other male sex hormones as a cause of infertility. 4- Estimate serum level of inhbin B in the studied groups. 5- Determine the relationship between serum inhbin B and total sperm count in infertile males.

A total number of (90) individual, in which 70 infertile male patients with period of infertility more than one year and 20 fertile males as control group. The study was carried out on patients attending infertility care in a period of one year from June 2011 to June 2012, 90 semen samples were studied for semen analysis and for serological (ASAs) test and 90 serum samples for serological (ASA) study by using micro agglutination test and for hormonal assay (Latinizing hormone (LH), Follicular stimulating hormone (FSH), testosterone, prolactin) and inhibin B by using Enzyme Linked Immunosorbent Assay (ELISA). There was no significant difference between patients and controls according to the serum level of (LH, FSH ,testosterone, and prolactin), antisperm antibodies found positive in sera and semen of $15(21.42 \%)$ of patients with titer $1 / 32$ on semen and 1/64 in serum. The remainder $55(78.57 \%)$ patients, showed negative results for (ASAs). There was a significant difference between mean $\%$ of total motility, mean $\%$ of normal sperm morphology and mean of total sperm counts of patients with positive ASAs results when compared to its mean in the control group. Mean concentration of serum inhibin B in patients with negative (ASAs) result was (32.24) pg/ml, while of control group was (73.55) $\mathrm{pg} / \mathrm{ml}$. The difference was considered highly significant. There was significant correlation between total sperm count of patients with negative ASAs results and mean concentration of serum inhibin B. This study suggests that the detection of ASAs in semen and sera of patients decrease in normal seminal fluid parameters especially the motility and (ASAs) can be considered as a cause of infertility in those patients, while low serum inhibin B in the reminder patients can be considered as a cause of infertility, then inhibin B can be considered as a marker for spermatogenesis.
\end{abstract}

Keywords: Male infertility, Antisperm antibodies, Inhibin B hormone. 


\section{الكثف عن الأجسالم المضاة للحيامن وعافتها بهرون لنهبينبف النكور غير الخصبن}

\section{الملغص}

تهوف الدرلسة إلى:1 - الكثف عن الأجسلم المضاة للحيلمن في اللسالل المذوي والبلازما المنوية

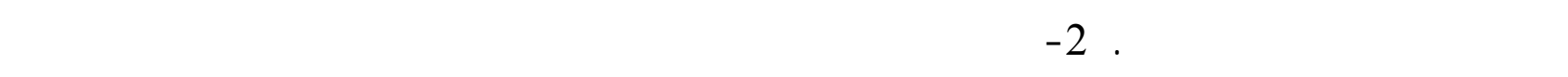

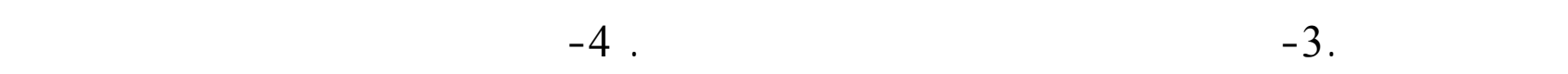

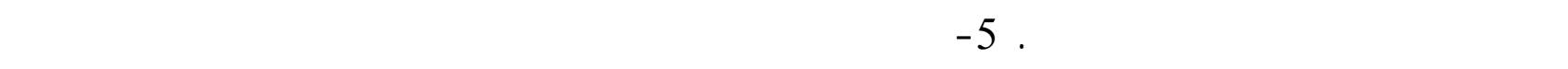
عدد الحيلمن في اللسال المنوي لدى الرجل غير الخصبين. لما تصميم الدرلسة فتشمل مقارنة الحالات

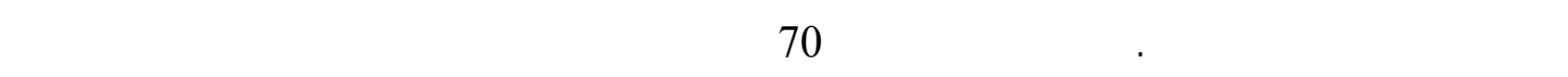

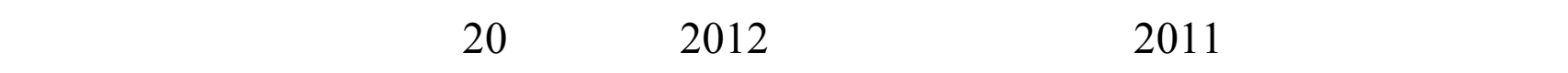

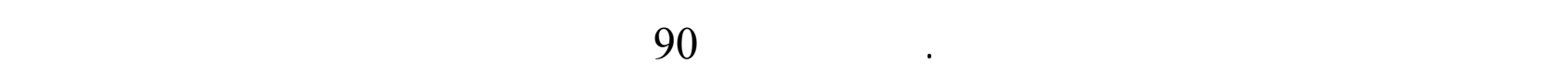
اللسائل المنوي ولإيجاد لجُسلم مضادة للطف، كما قم أخذ 90 عينة هم اللتحري عن الأجسلم المضادة للطفاف

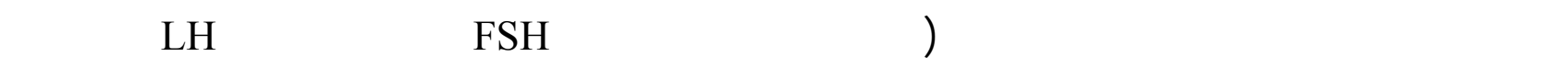

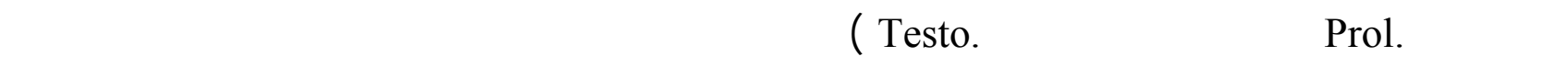

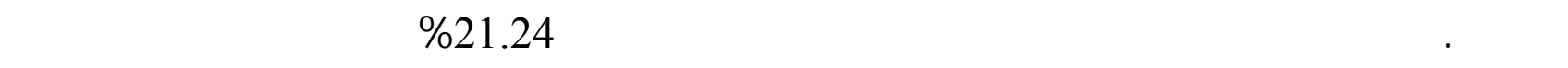

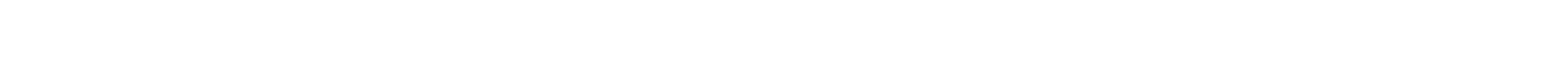

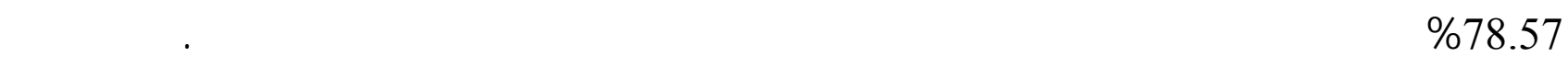

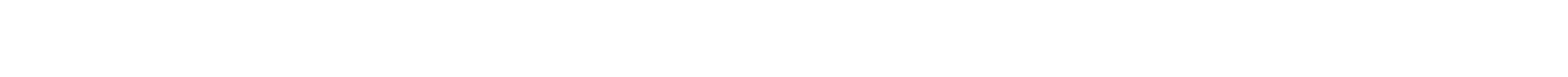

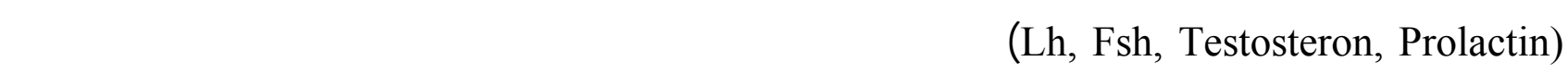

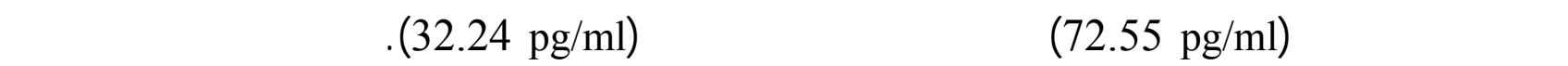

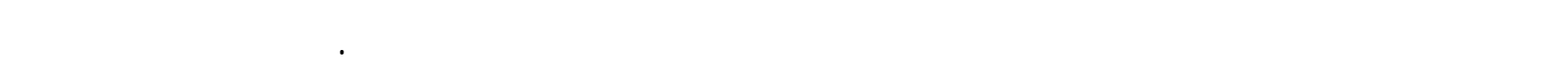

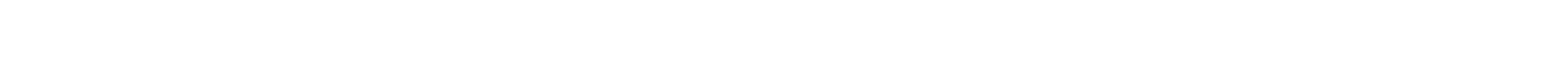

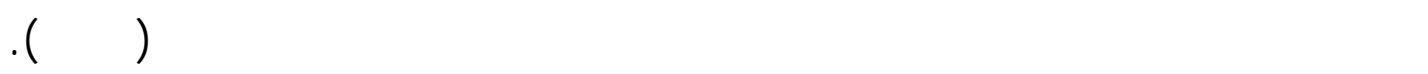

\section{INTRODUCTION}

Infertility is defined as the inability to achieve pregnancy after one year of unprotected intercourse. An estimated $15 \%$ of couples meet this criterion and are considered infertile, with approximately $35 \%$ due to female factors alone, $30 \%$ due to male factors alone, $20 \%$ due to combination of female and male factors, and $15 \%$ unexplained. Conditions of the male that affect fertility are still generally underdiagnosed and undertreated (Brugh and Lipshultz , 2004).

A male factor alone is the cause of infertility in up to $20 \%$ of infertile couples and a contributing factor in another $30 \%$ to $40 \%$ of all couples presenting for infertility 
evaluations (American Urological Association [AUA] and American Society for Reproductive Medicine (ASRM), 2004).

The major constituents of semen are; spermatozoa; fructose, which is produced by seminal vesicles, provides a source of energy for sperm motility; clotting and anticoagulated factors (Kacsoh, 2000; Guyton and hall, 2006). Causes of infertility in men can be explained by deficiencies in sperm formation, concentration (eg, oligospermia [too few sperm], azoospermia [no sperm in the ejaculate]), or transportation. The presence of antisperm antibodies (ASAs) was considered as one for the main causes of male infertility. (Hinting and Mahmoud, 1996). The production of ASAs is closely related to the stimulation of sperm antigen.

The initial evaluation of the male patient should be rapid, noninvasive, and costeffective, starting with semen analysis, the human sperm cell is paddle- shaped with a rounded head (4-5) microns long and 2-3 microns in width and a long tail of flagellum about 50 microns which contain a central contractile unit called as the axoneme (Rao et al., 2004). Treatment options are based on the underlying etiology and range from optimizing semen production and transportation with medical therapy or surgical procedures to complex assisted reproduction techniques (Ghanem et al., 2010).

Treatments of ASAs include: (i) condom use; (ii) washing, enzymatic treatment; (iii) split ejaculate, depletion; (iv) steroids; and (v) insemination, (IVF). Each of these therapies has its advocates (Francavilla et al., 2007).

Inhibin $\mathrm{B}$ is a glycoprotein hormone of gonadal origin, consisting of 2 dissimilar disulfide-linked subunits ( $\alpha$ and either $\beta$ A or $\beta B$ ), that has an inhibitory effect on pituitary gonadotropin production of FSH and LH (Illingworth et al., 1996).

Serum inhibin B is considered a marker of spermatogenesis. One major finding is that inhibin B is the physiologically important form of inhibin in the male. Inhbin B can cause male infertility, in which its serum level in infertile male is lower than fertile male.

\section{MATERIAL AND METHODS}

In this case -control study, the serum and semen from (70) infertile male patients attending infertility care in Erbil city and (20) fertile male as control group were collected. The study was carried out from June 2011 to June 2012. The sample size is determined by statistical program of Epi info version 6.

The total number of samples was 90 in which the serum from (70) infertile male patients and (20) fertile male as control group were collected. A total $5 \mathrm{ml}$ of blood was obtained by vein puncture, serum was separated by centrifugation and stored under $\left(-20^{\circ} \mathrm{C}\right)$ until analyzed (for serological tests).

A semen specimen was collected after 3 days of abstinence period, in a wide -mouthed, clean and sterile container. Each patient had been told to urinate before collection to decrease contamination of semen from debris or leukocytes (Eliasson,1986), carefully instructed to avoid inner contamination of container and wash the hands and glans penis with soap and water prior to masturbation. It is important that the entire specimen was collected. Semen was incubated for 30 minutes at $37{ }^{\circ} \mathrm{C}$ for liquefaction. Name, time of ejaculation and period of abstinence were mentioned (Chernecky and Berger, 1997). Part of these samples were used for semen analysis and the remaining of the seminal fluid was centrifuged at ( 3000 ) rpm for 15 minutes and the seminal plasma was freezed and stored 
at $\left(-20^{\circ} \mathrm{C}\right)$ to be used later for the detection of ASAs. 90 semen samples studied for semen analysis and for serological (ASAs) test and 90 serum samples for serological (ASA) study and for hormonal assay (LH,FSH, testoesteron, prolactin) and inhibin B done by using ELISA.

Normal seminal fluid sample from healthy fertile male having two kids was also, used as donor for sperm antigen. The ASAs in both sera and semen of studied group were done by using Tray agglutination test (TAT) or micro agglutination test (MAT).

Suitable inferential statistics were used to analyze the results which include:

1. Pearson Chi-squared test $\left(\chi^{2}\right)$.

2. Fisher exact test.

3. t-test which was used to find significant difference between the means of different groups.

A P-value less than 0.05 was considered statistically significant (S), and less than 0.01 considered highly significant (HS), P-value greater than 0.05 considered non significant (NS).

\section{RESULTS}

The highest number and percentage of patients were in age range (24-28)year and (3943) year with $20(28.57 \%)$ and $18(25.71 \%)$ respectively as Table (1) showed, and most frequent duration of infertility was (1-5) year with $60 \%$ (Table 2 ).

The present results showed that there was no significant difference between mean concentration of prolactin, $\mathrm{FSH}$, and $\mathrm{LH}$ in sera of patients compared to control group, $\mathrm{p}>0.05$, and although there was a significant difference in mean concentration of serum testosterone of patients compared to control group but it was still within normal range as the data presented in Table (3).

From the 70 samples of semen and serum of patients, only $15(21.42 \%)$ showed positive results of ASAs as shown in Table (4). The remainder 55 (78.57\%), showed negative results.

The highest number and percentage of patients with positive $(+v e)$ results of ASAs with Head-Head agglutination was 11 (73.33\%) (Table 5).

The data represented in table (6) showed that the highest number and percentage $(\%)$ of Normozoospermia was in patients with negative (-ve) ASAs 43 (47.7\%), while the whole control group was normozoospermia with $20(22.22 \%)$. The highest number and percentage of oligozoospermia and azoospermia patients were those with negative ASAs with 6 $(6.6 \%)$ for both, while only $2(2.2 \%)$ and $4(4.4 \%)$ respectively showed oligospermia, azoospermia in patients with positive ASAs.

Table (7) showed that there was a significant difference between mean total sperm count $* 10^{6}$ of control group (92.60) when compared to mean total sperm count in patients with -ve ASA and +ve ASA (47.30) and (38.53) respectively.

Table (8)showed the highest number and percentage of patients with +ve ASA had $<40 \%$ total motility (PR+NP) $11(12.22 \%)$, compared to -ve ASA patients who had 8 $(8.88 \%)$. All control group were having $40 \%$ total motility $(\mathrm{PR}+\mathrm{NP})$. The highest number and $\%$ of patients with zero total motility were in -ve ASA is patients $6(6.66 \%)$ compared to +ve group who had only $2(2.22 \%)$. 
Table (9) showed that there was a significant difference between mean $\%$ of total motility of control group which was (47.15) when compared to its mean in -ve and +ve ASA patients (27.78), (21.33) respectively.

Table (10) showed that all control group 20 (22.22\%) had 30\% normal morphology, the highest number and $\%$ of $<30 \%$ normal morphology presented in -ve ASA patients with $9(10 \%)$ compared to +ve ASA patients who had $2(2.22 \%)$. The highest number and $\%$ of zero $\%$ of normal morphology was in -ve ASA patients with $6(6.66 \%)$ compared to +ve ASA patients who had $2(2.22 \%)$.

Table (11) showed that there was significant difference between mean $\%$ of normal morphology of control group which was (67.3)\% when compared to its mean in -ve and +ve ASA patients $(48.18) \%,(44.00) \%$ respectively.

Table (12) illustrated that the highest number and \% of patients with positive ASAs results was in age range group (29-33) years, which represent 7 (10\%).

The data represented in Table (13) showed that mean concentration of serum inhibin B in patients with negative ASAs result was (32.24) $\mathrm{pg} / \mathrm{ml}$, while of control group was (73. 55) $\mathrm{pg} / \mathrm{ml}, \mathrm{p}<0.0001$ so the difference was considered highly significant.

Fig. (1) showed that there was a significant correlation between mean serum inhibin B $(\mathrm{pg} / \mathrm{ml})$ and mean total sperm count $* 10^{6} / \mathrm{ml}$ in patients with negative ASAs.

Table 1: Distribution of infertile patients according to age groups (year)

\begin{tabular}{|l|l|l|}
\hline $\begin{array}{c}\text { Age range roups } \\
\text { (year) }\end{array}$ & \multicolumn{1}{c|}{ Frequency } & percentage \\
\hline $19-23$ & 5 & 7.14 \\
\hline $24-28$ & 20 & 28.57 \\
\hline $29-33$ & 16 & 22.85 \\
\hline $34-38$ & 11 & 15.73 \\
\hline $39-43$ & 18 & 25.71 \\
\hline Total & 70 & $100 \%$ \\
\hline
\end{tabular}

Table 2: Distribution of patients according to duration of infertility in year

\begin{tabular}{|l|l|l|}
\hline \multicolumn{1}{|c|}{ Duration of infertility (years) } & \multicolumn{1}{c|}{ No. of patients } & percentage \\
\hline $1-5$ & 42 & 60 \\
$6-10$ & 22 & 31.42 \\
$11-15$ & 4 & 5.72 \\
$16-20$ & 2 & 2.85 \\
\hline Total & 70 & $100 \%$ \\
\hline
\end{tabular}

Table 3: Mean conc. of prolactin $(\mathrm{ng} / \mathrm{ml})$, Testosterone $(\mathrm{ng} / \mathrm{ml})$, LH(m.I.U/ml) and FSH (m.I.U/ml) in sera of study groups

\begin{tabular}{|c|c|c|c|c|c|c|}
\hline $\begin{array}{l}\text { Study } \\
\text { groups }\end{array}$ & NO. & $\begin{array}{l}\text { Mean conc. of } \\
\text { testosterone } \\
(\mathrm{ng} / \mathrm{ml})\end{array}$ & $\begin{array}{c}\text { Mean conc. of } \\
\text { prolactin (ng/ml) }\end{array}$ & $\begin{array}{l}\text { Mean conc. of LH } \\
(\mathrm{m} . \mathrm{I} . \mathrm{U} / \mathrm{ml})\end{array}$ & $\begin{array}{c}\text { Mean conc. } \\
\text { of FSH } \\
\text { (m.I.U/ml) }\end{array}$ & $\begin{array}{l}\text { Statistical } \\
\text { study }\end{array}$ \\
\hline patients & 70 & \begin{tabular}{|l|l|}
3.2 & S.
\end{tabular} & 8.8 & 8.55 & 7.8 & \\
\hline controls & 20 & 3.6 & 8.2 & 8.64 & 9.6 & N.S. \\
\hline
\end{tabular}


Table 4: Distribution of patients according to result of ASAs in serum and seminal plasma

\begin{tabular}{|l|l|l|l|}
\hline \multicolumn{1}{|c|}{ Results of ASA } & \multicolumn{1}{c|}{ number } & percentage & \multicolumn{1}{c|}{ Titer of ASA } \\
\hline In semen & & & \\
-ve ASA & 55 & 78.57 & ------ \\
+ve ASA & 15 & 21.42 & $1 / 32$ \\
\hline In sera & & & \\
-ve ASA & 55 & 78.57 & ------ \\
+ veASA & 15 & 21.42 & $1 / 64$ \\
\hline
\end{tabular}

Table 5: Types of sperm agglutination in semen of patients with + result for ASAs

\begin{tabular}{|l|l|l|}
\hline $\begin{array}{c}\text { Types of sperm } \\
\text { agglutination }\end{array}$ & $\begin{array}{c}\text { Number of patients +ve } \\
\text { ASA }\end{array}$ & \multicolumn{1}{c|}{ percentage } \\
\hline Head-head & 11 & 73.33 \\
\hline Head-tail & 2 & 13.33 \\
\hline Tail-tail & 2 & 13.33 \\
\hline Total & 15 & 100 \\
\hline
\end{tabular}

Table 6: Distribution of patients and control group according to WHO criteria (2010) regarding total sperm count $* 10^{6} / \mathrm{ml}$ :

\begin{tabular}{|c|c|c|c|c|c|c|c|c|}
\hline \multirow{3}{*}{ Study group } & \multicolumn{6}{|c|}{ sperm count $* 10^{6} / \mathrm{ml}$} & \multirow{2}{*}{\multicolumn{2}{|c|}{ Total }} \\
\hline & \multicolumn{2}{|c|}{ Normozoospermia } & \multicolumn{2}{|c|}{ oligozoospermia } & \multicolumn{2}{|c|}{ azoospermia } & & \\
\hline & NO. & $\%$ & NO. & $\%$ & NO. & $\%$ & No. & $\%$ \\
\hline $\begin{array}{l}\text { ASAs+ve } \\
\text { patient(15) }\end{array}$ & 9 & 10 & 4 & 4.4 & 2 & 2.2 & 15 & 16.2 \\
\hline $\begin{array}{l}\text { ASAs-ve } \\
\text { patient (55) }\end{array}$ & 43 & 47.7 & 6 & 6.6 & 6 & 6.6 & 55 & 60.7 \\
\hline Controls(20) & 20 & 22.22 & 0 & 0 & 0 & 0 & 20 & 22.2 \\
\hline Total & 72 & 79.92 & 10 & 11 & 8 & 8.8 & 90 & 100 \\
\hline
\end{tabular}

Table 7: Mean total sperm count* $10 \% \mathrm{ml}$ in samples of study groups

\begin{tabular}{|l|l|l|l|l|l|}
\hline \multirow{2}{*}{ Study group } & \multicolumn{5}{|c|}{ Mean total sperm count $\mathbf{*} \mathbf{1 0} / \mathbf{m l}$} \\
\cline { 2 - 6 } & $\underline{\text { No. }}$ & $\underline{\text { Range }}$ & mean & $\underline{\text { S.D. }}$ & $\begin{array}{l}\text { Statistical } \\
\text { analysis }\end{array}$ \\
\hline $\begin{array}{l}\text { +ve ASA } \\
\text { patients(a) }\end{array}$ & 15 & $0-60$ & 38.53 & 27.77 & $\begin{array}{l}\text { a-b } \\
\text { a-c* }\end{array}$ \\
\hline $\begin{array}{l}\text {-ve ASA } \\
\text { patients(b) }\end{array}$ & 55 & $0-80$ & 47.30 & 30.64 & $\begin{array}{l}\text { b-a } \\
\text { b-c* }\end{array}$ \\
\hline Controls(c) & 20 & $90-105$ & 92.60 & 7.21 & $\begin{array}{l}\text { c-a* } \\
\text { c-b* }\end{array}$ \\
\hline Total & 90 & ---------- & --------- & --------- & -------- \\
\hline
\end{tabular}

*The mean difference significant at the 0.05 level according to LSD. 
Table 8: Distribution of patients and control group according to WHO criteria (2010) regarding \% total motility (progressive+Non progressive)

\begin{tabular}{|l|l|l|l|l|l|l|l|l|}
\hline \multirow{3}{*}{ Study group } & \multicolumn{6}{|c|}{$\%$ of Total motility (PR+NP) } & \multicolumn{2}{c|}{ Total } \\
\cline { 2 - 9 } & \multicolumn{3}{|c|}{$>\mathbf{4 0 \%}$} & \multicolumn{2}{c|}{$<\mathbf{4 0 \%}$} & \multicolumn{2}{c|}{ zero } & \multicolumn{2}{c|}{} \\
\cline { 2 - 9 } & NO. & \% & NO. & \% & NO. & \% & No. & \% \\
\hline $\begin{array}{l}\text { ASAs+ } \\
\text { patient(15) }\end{array}$ & 2 & 2.22 & 11 & 12.22 & 2 & 2.22 & 15 & 16.66 \\
\hline $\begin{array}{l}\text { ASAs- } \\
\text { patient(55) }\end{array}$ & 41 & 45.55 & 8 & 8.88 & 6 & 6.66 & 55 & 61.22 \\
\hline Controls(20) & 20 & 22.22 & 0 & 0 & 0 & 0 & 20 & 22.22 \\
\hline Total & 63 & 69.99 & 19 & 21.10 & 8 & 8.88 & 90 & $100 \%$ \\
\hline
\end{tabular}

Table 9: Mean percentage of total motility $(\mathrm{PR}+\mathrm{NP})$ in study groups

\begin{tabular}{|l|l|l|l|l|}
\hline \multirow{2}{*}{ Study group } & \multicolumn{4}{|c|}{ Mean \% of total motility(PR+NP) } \\
\cline { 2 - 5 } & No. & mean & S.D. & Statistical study \\
\hline $\begin{array}{l}\text { +ve ASA } \\
\text { patients(a) }\end{array}$ & 15 & 21.33 & 16.08 & $\begin{array}{l}\text { a-b } \\
\text { a-c* }\end{array}$ \\
\hline $\begin{array}{l}\text {-ve ASA } \\
\text { patients(b) }\end{array}$ & 55 & 27.78 & 19.63 & $\begin{array}{l}\text { b-a } \\
\text { b-c* }\end{array}$ \\
\hline Controls(c) & 20 & 47.15 & 8.05 & $\begin{array}{l}\text { c-a* } \\
\text { c-b* }\end{array}$ \\
\hline Total & 90 & --------- & --------- & --------- \\
\hline
\end{tabular}

Table 10: Distribution of patients and control group according to WHO criteria (2010)* regarding \% of normal morphology

\begin{tabular}{|c|c|c|c|c|c|c|c|c|}
\hline \multirow{3}{*}{ Study group } & \multicolumn{6}{|c|}{ \% of normal morphology } & \multirow{2}{*}{\multicolumn{2}{|c|}{ Total }} \\
\hline & \multicolumn{2}{|c|}{$\begin{array}{l}\text { normal } \\
\text { morphology } \\
\mathbf{3 0 \%} \\
\end{array}$} & \multicolumn{2}{|c|}{$\begin{array}{l}\text { normal } \\
\text { morphology } \\
<\mathbf{3 0 \%}\end{array}$} & \multicolumn{2}{|c|}{$\begin{array}{l}\text { Normal } \\
\text { morphology } \\
\text { \% zero }\end{array}$} & & \\
\hline & NO. & $\%$ & NO. & $\%$ & NO. & $\%$ & NO. & $\%$ \\
\hline $\begin{array}{l}\text { ASAs+ } \\
\text { patient(15) }\end{array}$ & 11 & 12.22 & 2 & 2.22 & 2 & 2.22 & 15 & 16.66 \\
\hline $\begin{array}{l}\text { ASAs- } \\
\text { patient(55) }\end{array}$ & 48 & 53.33 & 9 & 10 & 6 & 6.66 & 55 & 61.22 \\
\hline Controls(20) & 20 & 22.22 & 0 & 0 & 0 & 0 & 20 & 22.22 \\
\hline Total & 79 & 87.77 & 11 & 12.22 & 8 & 8.88 & 90 & 100 \\
\hline
\end{tabular}

- According to the WHO criteria max. reference of normal morphology is $30 \%$. 
Table 11: Mean percentage of normal morphology in study group

\begin{tabular}{|l|l|l|l|l|}
\hline \multirow{2}{*}{ Study group } & \multicolumn{4}{|c|}{ mean \% of normal morphology } \\
\cline { 2 - 5 } & No. & mean & S.D. & Statistical analysis \\
\hline $\begin{array}{l}\text { +ve ASA } \\
\text { patients(a) }\end{array}$ & 15 & 44.00 & 19.19 & $\begin{array}{l}\text { a-b } \\
\text { a-c* }\end{array}$ \\
\hline $\begin{array}{l}\text {-ve ASA } \\
\text { patients(b) }\end{array}$ & 55 & 48.18 & 21.88 & $\begin{array}{l}\text { b-a } \\
\text { b-c* }\end{array}$ \\
\hline Controls(c) & 20 & 67.3 & 8.16 & $\begin{array}{l}\text { c-a* } \\
\text { c-b* }\end{array}$ \\
\hline Total & 90 & ---------- & ------- & ------- \\
\hline
\end{tabular}

Table 12: Distribution of +ve ASAs patients according to age groups

\begin{tabular}{|l|l|l|}
\hline \multirow{2}{*}{ Age range groups (year) } & \multicolumn{2}{|l|}{ +ve ASAs in both semen and serum } \\
\cline { 2 - 3 } & Number of patients & \% \\
\hline $19-23$ & 0 & 0 \\
\hline $24-28$ & 2 & 2.8 \\
\hline $29-33$ & 7 & 10 \\
\hline $34-38$ & 4 & 5.7 \\
\hline $39-43$ & 2 & 2.8 \\
\hline Total & 15 & 21.42 \\
\hline
\end{tabular}

Table 13: Relationship between mean conc. of serum inhbin B in patients with negative result for ASAs and mean of controls

\begin{tabular}{|l|l|l|l|l|}
\hline \multicolumn{1}{|c|}{ Study groups } & $\begin{array}{c}\text { Range of serum } \\
\text { conc. of inhbin B } \\
\mathbf{( p g / m l )}\end{array}$ & Mean con. of inhbin B pg/ml & SD & S.S \\
\hline Patients (55) (-ve ASAs) & $20-75$ & 32.24 & 13.75 & \\
\hline Controls(20) & $40-135$ & 73.55 & 20.78 & $\begin{array}{l}\text { Highly } \\
\text { significant }\end{array}$ \\
\hline
\end{tabular}

$\mathrm{P}<0.0001$ at (2-Tailed).

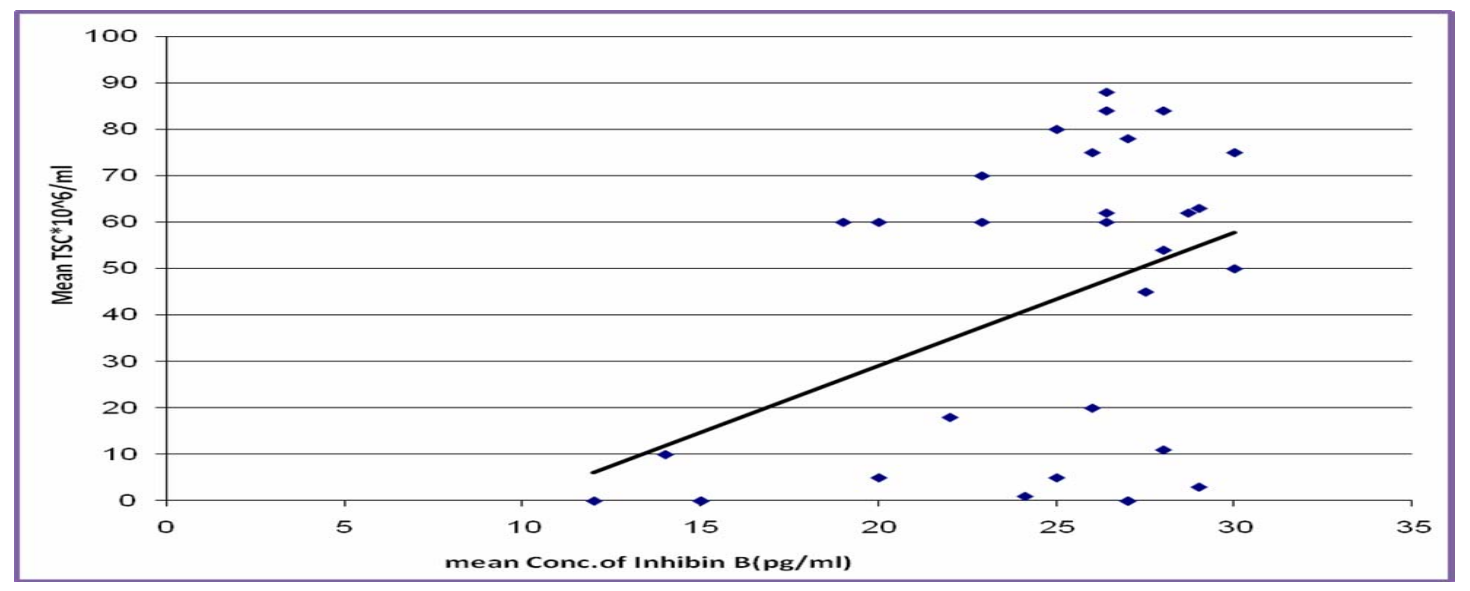

Fig. 1: Correlation between mean conc. of inhibin $B$ in $\mathrm{pg} / \mathrm{ml}$ and mean total sperm count* $10 \% / \mathrm{ml}$ in patients with negative results for antisperm antibodies 


\section{DISCUSSION}

This study stated that most patients were in the age range groups of (24-28) years and (39-43) years, this finding agreed with the finding of Gardi (2005) who reported that most common age presentation of male infertility is around (25-31) years. It has been suggested that the aging male has reduced fertility that begins in his late thirties and early forties (Bayer et al., 2007).

Gnoth et al., (2005) found that in general cumulative probabilities of conception decline with age. Sharon et al., (2001) concluded that increased male age is associated with a decline in semen volume, sperm motility and sperm morphology. The highest percentages of patients have duration of infertility about (1-5) years in this study and this agreed with Abdullah (2009) who observed the highest percentage of infertile male patients in duration between (1-4) years.

This short duration may be due to the awareness of the public about the reproductive techniques and this is due to media attention.

Allow (1999) stated that the introduction of IVF, which increased the possibilities for effective treatment for infertile couples is partially due to the media attention, paid to these techniques. The result of this study disagreed with one study that stated the highest $\%$ of infertile patients were having duration of infertility between (1-8) years (Gardi, 2005).

Table (3) revealed that there was no significant difference between mean concentration of prolactine in sera of patients and control group, $(\mathrm{p}>0.5)$.

The result of this study are supported by studies of Beltran et al., (2008) who demonstrated that mean concentration of prolactin in sera of adult men was (7.8) ng/ml, and Greenspan et al., (2003) who found that up to $15 \mathrm{ng} / \mathrm{ml}$ of serum prolactin is normal in men.

The present results showed that there was a significant difference between mean concentration of testosterone in sera of patients (3.2) $\mathrm{ng} / \mathrm{ml}$ when compared to its mean in sera of control group (3.6) $\mathrm{ng} / \mathrm{ml} \quad(\mathrm{p}>0.05)$. Testosterone is necessary for normal sperm development. It activates genes in Sertoli cells, which promote differentiation of spermatogonia (Mehta et al., 2008). This agree with the results of Fischbach (1998) who found that the normal value of adult testosterone is between (3-10) $\mathrm{ng} / \mathrm{ml}$, this result proved that patients and control group had normal serum testosterone. The data also showed that the mean concentration of LH in sera of patients was (8.5) m.I.U./ml, while of control group was (8.6) m.I.U./ml, so the difference was not significant, $\mathrm{p}>0.05$.

The results above agree with Greenspan et al., (2003) who found that the normal value of LH in adult male was between (2-14) m.I.U/ml.

The data represented in table(3) showed that there was no significant difference between mean concentration of FSH in sera of patients when compared to its mean in control group, the range of serum concentration of FSH of control group was between (5-14) $\mathrm{m} . \mathrm{I} . \mathrm{U} / \mathrm{ml}$.

The results agree with Greenspan et al., (2003) who found that the normal serum FSH ranges between (1-12) m.I.U/ml.

A number of reports described the association between ASAs with the occurrence of infertility in either men or women, although usually the unexplained infertility has been the point of emphasis (Shulman et al., 2005). 
Antisperm antibodies can be defined as immunoglobulines of the IgG, IgA and/or IgM classes that are directed to various aspects of spermatozoa (head, tail, midpiece or combination).

The sperm antibodies in men are polycolonal that is directed to more than one sperm antigen. The possible effects of immunologic reaction to fertility are:

1. Disordered spermatogenesis resulting in oligozoospemia and azoospermia.

2. Binding of antibodies to post testicular spermatozoa inhibiting their effective transport in male reproductive tract.

3. Induction of sperm immunity in the female. (Bennet, 1997; Mazumdar and Levine, 1998; Karaki et al., 2000).

Table (4) showed that the distribution of ASAs which was detected by using MAT in the sera of patients and control group sera and seminal plasma was $(21.42 \%)$.This result is in agreement with that of Al-Khayat (2004) who observed (22.3\%) positive ASAs in male serum of 130 cases studied by (TAT) method.

A study in Kirkuk governorate by Marbeen et al., (2007) found that by using ELISA, ASA was detected in the seminal fluid of (25.8\%) infertile. Abdullah (2009) found that positive ASAs in semen and serum was $(29.94 \%),(21.01 \%)$ respectively in 157 infertile couples in Erbil city. Ameen (2007) found that $6.03 \%$ of 223 infertile male in Kurdistan have ASAs in seminal plasma by using TAT.

Agglutination means adhering spermatozoa without other cells or debris. Small aggregates of dead spermatozoa often found in semen from normal men (Kuist and Bjorndahi, 2002).

Table (5) showed that the highest number and \% of patients $11(73.33 \%)$ had sperm agglutination of Head-Head type.

The ASAs directed against the sperm head were of primary importance, whereas those the tail were involved in poor motility. Moreover, ASA-coated sperm may be more vulnerable to phagocytosis in the female reproductive tract. (Lombardo et al., 2001).

Modification of sperm motility is the main cause of infertility in some patients, resulting in blockage of transport to, and union with, the oocyte (Rooney et al., 1993).

It is very difficult to tell an infertile man how many sperms needed for conception. In this study, the chamber method for the evaluation of sperm count used is due to its accuracy and reliability in keeping with several articles (Sarkar and Henry,1996).

Table (6) showed that control group was all normozoospermia, while there was oligospermia and azoospermia in +ve ASAs patients with 4(4.4\%), 2(2.2\%) respectively.

This result goes with Abdullah (2009) who delineated that Abnormal seminal fluid parameters which include sperm count related to the presence of antisperm antibodies in semen of infertile patients. Mardar et al.,(2002) found that antisperm autoimmunity appears to play a significant role in impairment of spermatogenesis.

Table (7) showed that the mean total sperm count of control group was $92.60^{*} 10^{\wedge} 6 / \mathrm{ml}$ which was higher than the mean of $+v e$ and $-\mathrm{ve}$ ASAs infertile patients.

These results were in agreement the with finding of Shen et al., (1999); Chia et al., (2000); Okonofua et al., (2005) and Ameen (2007) who recorded that sperm concentration and total sperm count from healthy fertile men are higher than infertile men. Khosrowbeygi et al., (2004) found that sperm concentration is higher in fertile group men than in asthenozoospermic, asthenoteratozoospermic, and ligoasthenoteratozoospermic patients. 
Regarding motility and According to WHO (2010) criteria and as table (8) showed that all control group having $>40 \%$ total motility, while $8(8.88 \%)$ of - ve ASA and $11(12.2 \%)$ of +ve ASAs patients had $<40 \%$ total motility.

This result is in agreement also with the studies of Chia et al., (2000); Okonofua et al., (2005); and Ameen (2007). They observed that sperm motility in infertile men are lower than that of fertile men.

Table (9) showed that there was a significant difference between mean $\%$ of total motility $(\mathrm{PR}+\mathrm{NP})$ of +ve ASA patients when compared to its mean in control group.

The above data agree with Abdullah (2009) who found that ASAs in semen affect sperm motility in infertile male. ASAs can negatively affect sperm motility, (Bohring et al., 2004).

Another study stated that abnormalities in motility and quality of movements can arise from the presence of ASAs (Seaman et al., 1994).

Sperm motility is an important factor in the fertilization potential of the sperm, and motility has been shown to correlate closely with the fertilization rates of human oocyte In vitro (Schultel et al., 2008).

Table (10) showed that the control group had 30\% normal sperm morphology, while the -ve ASA patients groups had $9(10 \%)$ of $<30 \%$ normal sperm morphology and $6(6.6 \%)$ of zero \% of normal sperm morphology.

The result of this study is in agreement with the finding by Ameen (2007) who reported a high normal sperm morphology in normozoospermic group compared to other groups like oligoasthenozoospermic group. Khosrowbeygi et al., (2004), showed that normozoospermic fertile men have higher normal sperm morphology than oligoasthenoteratozoospermic, asthenozoospermic, and asthenoteratozoospermic infertile men.

Table (11) showed that mean \% of normal sperm morphology in control group was higher than its mean in +ve ASAs patients, and there was a significant difference between the two. $p>0.05$

The presence of ASAs affect the morphology of sperm in semen of infertile patients (Abdullah, 2009).

The current study delineates that there is a significant relation between abnormal variable of SFA and the presence of ASA in semen.

In this study, there is a significant relation between ASAs in male serum and semen with abnormal seminal fluid parameters and this is supported by studies of Devin et al., (1993); Kipersztok et al., (2003); Brandy et al., (2003). WHO found that positive semen samples had a significant abnormal sperm count, low motility, and morphology (WHO, 2010).

This study showed that positive ASAs were associated with abnormal variable of seminal fluid. Marbeen et al., (2007) found that the highest percentage of positive ASAs was associated with abnormal seminal fluid parameters.

Garcia et al., (2007) intended to detect the presence of ASA and their incidence in men with unexplained infertility indicated that ASA are involved in reduced infertility and a correlation between infertility and altered seminal parameters reinforce the ASA participation in this pathology.

Experimental studies indicate that infertility may have an immune basis, resulting from spontaneous or induced autoimmune diseases that target the testis, ovary, or the spermatozoa (Tung, 1998). Two immunological mechanisms may be operateve in these 
diseases; first, sperm antibodies which incapacitate spermatozoa motility or viability by complement-dependant cytotoxity, interferance with their transport in the female genital tract, or blockage of cellular interaction in the fertilization process. Second, T-cell mediated inflammation may result in atrophy of the gonads associated with loss of germ cells (Rose et al., 2002).

The study indicated that highest percentage of serum and semen ASAs was in the age group (29-33) years as illustrated in Table (12).

This study goes also with Abdullah (2009) who indicated that the highest percentage of serum ASAs was in the age group (25-34) years in Erbil city and with that of Hossain et al., (2007) who indicated that the age related variations in the incidence of ASAs might suggest that the vulnerability of different age groups to immunological imbalances is not the same.

A study by Collins et al., (1993) and Heidenreich et al., (1994) found that ASAs, in both sexes, increased with age, this probably suggests that age may be a contributing factor in induction of ASAs.

The study showed a significant difference between mean serum conc. of inhibin B of control group and its mean in - ve ASA patients as shown in table (13) $p<0.0001$. This result agree with which is found that serum concentration of inhibin B in infertile male was lower than serum concentration in fertile control group (Gavin et al., 2009), and with study that stated that serum inhibin B concentration were significantly higher in fertile control group than serum concentration of inhibin B in patients with primary testicular failure (Bradford et al., 2000).

Mean serum inhibin B in $\mathrm{pg} / \mathrm{ml}$ was found to be lower in infertile males than normal control group in the study of Kumanovp et al., (2006).

As data illustrated in Fig. (1) there was significant correlation between concentration of inhbin B in sera of -ve ASAs patients and total sperm count of those patients, which agrees with the study that concluded that serum inhbin B concentration an interesting marker for spermatogenesis (Pierik, 1998).

Inhbin B level correlated positively with total sperm concentration as found by Gavin (2009) and this goes with result of this study.

The sperm count may be affected by many factors such as hormonal. Some causes of azoospermia related to hormonal imbalance, (Kondoh et al., 1999).

Anderson (2004) found that inhibin-B levels decreased consistently with the decrease in spermatogenesis. Therefore, spermatogenesis partially determines inhibin-B levels. A study of (Gavin, 2009) stated that inhbin B correlated positively with sperm count, but the predictive power is best when inhbin B is low.

There are some studies confirm that serum inhbin B level reflects testicular function and more precisely sertoli function (Anawalt et al., 1996).

There was a study done by Frank et al.,(1998) demonstrated a significant correlation between sperm concentration, sperm count, and testicular volume on the one hand, and serum inhibin B levels on the other.

These results provide a strong evidence that inhibin B is an important marker of the competence of sertoli cells and spermatogenesis in the human, which is in accordance with the few reports on inhibin B and quality of spermatogenesis up to now (Illingworth et al.,1996; Anawalt et al.,1996). 


\section{CONCLUSIONS}

Antisperm antibodies are present in both serum and semen of patients and this affecting normal seminal fluid parameters of these patients. Serum inhibin B (pg/ml) lower in infertile male than fertile male and inhbin B has an effect on total sperm count and can cause male infertility. Also serum inhbin B was considered as marker for spermatogenesis.

\section{ACKNOWLEDGEMENT}

I would like to express my deepest gratitude and respect to Dr. Nabeel E. Fatouhi assistant prof. in mmunology in medical college in Erbil University for his help and advice, meticulous supervision, and guidance throughout the execution of this study. Also I am very grateful to Dr. Honar Abdul- Kader and Mr. Mwafaq who work in infertility clinic in Erbil city.

\section{REFERENCES}

Anawalt, B.D.; Bebb, R.A.; Matsumoto, A.M.; Groome, N.P.; Illingworth, P.J.; McNeilly, A.S.; Bremner, W.J. (1996). Serum inhibin-B levels reflect Sertoli cell function in normal men with testicular dysfunction. J. Clin. Endocrinol. Metab., 81, 33413345.

Allow, A.K. (1999). Treatment and in vitro sperm activation for immunologically infertile patients. M. Sc. Thesis, College of Medicine, Kufa University, 105 p.

Al-Khayat, Z.A. (2004). Sero-Bacterial assessment of asymptomatic infertile males in Erbil. Ph.D. Thesis, Erbil, Salahaddin University, College of Medicine.

Abdullah, S. (2009). The effect of serum and semen antisperm antibodies on the post coital test and semen fluid parameters among infertile couples in Erbil governorate. M.Sc. Thesis. Hawler Medical University in Erbil city.

Ameen, E.D.(2007). A Diagnostic study of some causes of male infertility in Kurdistan region of Iraq. Ph.D. Thesis, Babylon University, College of Science.

American Society for Reproductive Medicine (ASRM) (2004). Sexual dysfunction. USA. Fertile thoughts Inc. pp.1-2.

Andreson, A.M.; Petersen, J.H.; Jorgensen, N.; Jensen T.K.; Skakkebaek, N.E. (2004). Serum inhibin B and FSH levels as a tools in the evaluation of infertile men as a significance of adequate refrences values from proven fertile men. J. Clin. Endocrine Metab., 89, 2873-2879.

Bayer, R.S.; Alper, M.M.; Penzias, A.S. (2007). "The Boston IVF Hand Book of Infertility". 2nd ed. USA. The Pathenon Publishing groups.

Bennet, W.A.(1997). "Reproductive Immunology". Clinical Reproductive Medicine. USA. Lippincott-Raven publisher. pp. 247-265.

Beltran, L.; Fahie, M.N.; McKenna, T.J.; Kavanagh, L; Smith, T.P.(2008). Serum total prolactin and monomeric prolactin reference intervals determined by precipitation with polyethylene glycol: evaluation and validation on common immunoassay platforms. Clinical Chemistry., 54 (10), 1673-1681.

Bohring, C.; Klepper, L.; Krause, W. (2004). Localization of binding sites of naturally occurring antisperm antibodies on human spermatozoa immunofluorescence. Andrologia., 36, 286- 290.

Bradford, A. K.; Frank, Z.; Stanczy, K.; Rebecca, Z. ; Sokol, (2000). Serum inhibin B level in males with gonadal dysfunction. Infertility and Sterility., 74, 243-248. 
Brandy, D.; Kim, D.; Laurra, M. (2003).Validity of rapid assay for antisperm antibodies in semen. Fertil Steril., 79(3), 522-8.

Brugh, V.M.; Lipshultz, L.I. (2004). Male factor infertility: evaluation and management. Med. Clin. North Am., 88 (2), 367-385.

Chernecky, C.C.; Berger, J.B. (1997). "Laboratory Tests and Diagnosis Procedures". 2nd ed. Philadelphia. W. B. Saunders Company.

Chia, S.E.; Lim, S.T.A.; Tay, S.K.; Lim, S.T. (2000). Factors associated with male infertility: a case -control study of 218 infertile and 240 fertile men. BJOG., 101(1), 55-61.

Collins, J.A.; Burrows, E.A.; Yeo, J.; Young, E.V. (1993). Frequency and predictive value of antisperm antibodies among infertile couples. Hum. Reprod., 8(4),592-598.

Devin, P.; Sedensky, J.; Jordan, S. (1993). Detection semen antisperm antibodies in the clinical laboratory. Arch Pathol Lab Med., 117(8), 784-788.

Eliasson, R. (1986). "Semen Analysis as a Tool in the Search for a Male Contraceptive". In: Zatuchin, G.I.; Goldsmith, A.; Spieler, J.; Sciarra, J.J. and Harper. "Male Contraceptive: Advances and Future Prospects". Philadelphia. Paulsen Academic Press. pp. 114-123.

Francavilla, F.; Santucci, R.; Barbonetti, A.; Francavilla, S. (2007). Naturally occurring antisperm antibodies: interference with fertility and clinical implication. An update. Front Biosci., 12, 2890- 2911.

Frank, H.C.; Yehia, F.; Ali , F.; EL Arini, F.; Adel, H.; Sami, A. (1998). Relation between seminal plasma of inhibin B and spermatogenesis. JCEM., 83, 3110-3114.

Fischbach, F.T. (1998). A manual of laboratory and diagnostic tests. Lippincott, Philadelphia. ISBN: 039755186X.

Gardi, A. H. (2005). Assessment of Psychosocial aspect of infertile women in ErbilKurdistan region - Iraq. M.Sc. Thesis. University of Salahaddin, College of Nursing.

Gavin, M.; Myers, A.B.; Geralyn, M.; Lambert, M.; Mark, S. (2009). Inhibin B refrences data for fertile and infertile males. Fertility and Sterility. 92(6), 1920-1923.

Gnoth, C.; Godehardi, E.; Herrmann, P.F.; Friol, K.; Tigges, J. ; Freundl, G. (2005). Debatecontiued: Definition and prevalence of subfertility and infertility. Hum Reprod., 2(5), 1144-1147.

Greenspan, F.S.; Gardner, D.G. (2003). "Basic and Clinical Endocrinology". 7th ed. Norwalk: Appleton-Lange, ISBN: 007140297.

Garcia, P.C.; Patricia, C.; Rubio, M.A.; Eliana, M.; Oduvaldo, C.M. (2007). Antisperm antibodies in infertile men and their correlation with seminal parameters. Reprod Med Biol., 6(1), 33-38.

Ghanem, H.; Shaeer, O.; El-Segini, A. (2010). Combination clomiphene citrate and antioxidant therapy for idiopathic male infertility: A randomized controlled trial. Fertil Steril., 93(7), 2232-2235.

Guyton, C.A.; Hall, E.J. (2006). "Female Physiology Before Pregnancy". In: Schmitt, W. ; Belfus, L.; Gruliow, R.; Rebane, T. "Text Book of Medical Physiology". 11th ed. Philadelphia, USA. Elsevier Saunders. pp. 1011- 1024.

Hinting, A.; Mahmood, A.M. (1996). "Immunological causes of male infertility". 1st ed. "Male Infertility Causes and Management. Belgium". Chapman and Hall Medical publisher. pp. 223-228. 
Hossain, A.; Islam, N.; Aryal, S.; Madanes, A. (2007). The prevalence of circulating antisperm antibodies (ASA) in infertile population representing of all etiologies. Middle East Fertility Society. 12(1), 27-30.

Heidenreich, A.; Bonfig, R.; Wilbert, D.M. ; Engelmann, U.H. (1994). Risk factors for antisperm antibodies in infertile men. Amer. J. Reprod Immunol., 31. 69-76.

Illingworth, P.J.; Groome, N.P.; Byrd, W.; Rainey, W.E.; McNeilly, A.S.; Mather, J.P.; Bremner, W.J. (1996). Inhibin-B. A likely candidate for the physiologically important form of inhibin in men. J. Clin. Endocrinol. Metab., 81, 1321-1325.

Kacsoh, B. (2000). "Reproductive Endocrinology. Endocrine Physiology". New York. McGraw-Hill. pp. 448-639.

Karaki, Raja, Z.; Al-Mously, A. (2000). A comprehensive review onimmunoinfertility relevant aspects to assisted conception. Middle East Fertility Soc. J., 5(20), 87-95.

Kipersztok, S.; Kim, B.; Morris, L.; Drury, K. (2003). Validity of rapid assay for antisperm antibodies in semen. Fertil Steril., 79(3), 522-528.

Kondoh, N.; Fujimoto, M.; Takemaya, M.; Nakamura, Y.; Kitamura, M.; Matsumiya, K.; Okuyama, A. (1999). Treatment of azoospermia patient with genitourinary tuberculosis: a case report. Hinyokika -Kiyo, 45(3), 199-201.

Kuist, U.; Bjorndahi, L. (2002). "Manual on Basic Semen Analysis". Nafa and Eshre -Siga. Eshre monographs. Oxford, United Kingdom. Oxford University Press. pp. 1-31.

Kumanovp, T.A.; Agarwal, A. (2006). Inhibin B is a better marker for spermatogenesisthan other hormones in the evaluation of male factor infertility. Fertile Sterile, 86, 3328.

Khosrowbeygi, A.; Zarghami, N. ; Delder, Y. (2004). Correlation between sperm quality parameters and seminal plasma antioxidant status. Iranian J. Reproductive Medicine, 2(2), 58-64.

Lombardo, F.; Gandini, L.; Dondero, F.; Lenzi, A. (2001). Immunology and immunopathology of the male genital tract - antisperm immunity in natural and assisted reproduction. Hum Reprod Update, 7, 450- 456.

Marbeen, M.I.; Bra, D.H.; Ghalib, A.K. (2007). The incidence of seminal antispermantibodies in infertile males in Kirkuk governator. J. Zankoy Sulimani, 10(1), 15-20.

Mazumdar, S.; Levine, A.S. (1998). Antisperm antibodies etiology, Pathogenesis, diagnosis and treatment. Fertil Steril., 70(5),799-810.

Mardar, J.; Urbảnek, V.; Chaloupkovả, A.; Nouza, K.; Kinskỷ, R. (2002). Role of spermantibodies and cellular autoimmunity to sperm in the pathogenesis of maleinfertility. Ceska Gynekol., 67(1), 3-7.

Mehta, P.H.; Jones, A.C.; Josephs, R.A. (2008). The social endocrinology of dominance: basal testosterone predicts cortisol changes and behavior following victory and defeat. J. Pers. Soc. Psychol., 94 (6),1078-1080.

Okonofua, F.; Menakaya, U.; Onemu, S.O.; Omo-Aghoja, L.O. ; Bergstrom, S. (2005). A case -control study of risk factors for male infertility in Nigeria. Asian J. Reprod. Immunol. Androl., 7(4), 351- 361.

Pierik, F.H.; Vreeburg, J. T.; Stijuen, T.; De Jong, F.H.; Weber, R.F. (1998). Serum inhbin B as a marker for spermatogenesis. J. Clin., End. Metab., 83, 3110-31104.

Rao, K.A.; Brnsden, P.R.; Sathananthan, A.H. (2004). "The Infertility Manual". 2nd ed. New Delhi. Jaypee Brother's Medical Publishers (p) Ltd. 
Rose, N.R.; Hamilton, R.G.; Detrick, B. (2002). "Autoimmunity of Testis, Ovary, and Spermatozoa. Manual of Clinical Laboratory Immunology". 6th ed. Washington: American society for microbiology, DCP. pp. 1054-1059.

Rooney, I.A.; Oglesby, T.J.; Atkinson, J.P. (1993). Complement in human reproduction: Activation and Control, 12, 276- 294.

Sarkar, S.; Henry, J.B. (1996). "Andrology Laboratory and Fertility Assessment". In: Sakar editor. Clinical Diagnosis and management by laboratory Methods. 19th ed. USA. W. B. Saunders Company. pp. 507- 513.

Seaman, E.; Bar-Chama, N.; Fisch, H. (1994). Semen analysis in the clinical evaluation of infertility. Mediguide to Urology, 7, 1-8.

Schultel, T.R.; Keller, M.L.; Hiner, R.M.; Ohl, A.D.; Smith, D.G. (2008). Temporal decreases in sperm motility: Which patient should have motility checked at both One and two hours after collection. J. Androl., 5, 481- 492.

Shulman, S.; Miniberg, D.T.; Davis, J. E. (2005). Significant immunological factors in male infertility. J. Urol., 119, 231- 34.

Sharon, A.K.; Brenda, E.; Andrew, J.W. (2001). Effects of male age on semen quality and infertility. Fertil Steril., 75(2), 237- 48.

Shen, R.K.; Chia, S.E. ; Ong, C.N. (1999). Evaluation of oxidative DNA damage in human sperm and its association with male infertility. J. Androl., 2(6), 718- 23.

Tung, K.S. (1998). "Autoimmune Diseases of the Testis and the Ovary". The Autoimmune Diseases. 3rd ed. San Diego, California. Academic Press, Inc. pp. 608-704.

WHO (World Health Organization) (2010). "WHO Laboratory Manual for Theexamination of Human Semen and Sperm Cervical Mucus Interaction". 4th ed. World health organization. Cambridge University Press. 